\title{
甘酒を原因食とする食中毒に関する基礎的研究
}

\author{
第 I 報 甘酒中毒の疫学
}

\section{Fundamental Studies on the Food Poisoning by Amasake}

I. Epidemiological Investigation on the Amasake Food Poisoning

東京医科歯科大学医学部農村厚生医学研究施設 (主任 柳沢交徳教授)

宇 井進 治

Shinji Ui

Institute of Medical Research for Rural Welfare, Tokyo Medical and Dental University

(Director: Prof. F. Yanagisawa)

\section{I. 緒言}

甘酒忍日本独特の甘味领料で，古代に活口の中で飯主 かみくだいて器中に集めて唾液中の糖化酻素它利用して

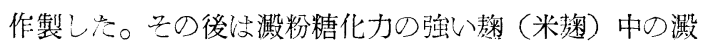
粉糖化醏素 Amylase および Maltase 尘利用して米飯, 粥などに混合して作用させ50 60 $\mathrm{C}$ 前後に保管して独特 の風味妾さつ甘酒老つくつた。この甘酒は米飯中の澱粉 在デキストリン, 麦芽糖, ブドウ糖に糖化さしめたもの で, 甘味も強く, 芳香孝有し古来日本で愛好されてい る。甘酒は企業的に商売人によつて製造されて発売され る場合も㐫るが, 大部分とくに農山村に妏てては自家製 で祝日や集会用に利用されている。なかその製造工程は 地方心よつて多少異なるが医よるど同じであるようであ る。近年の厚生省食中毒統計資料によると甘酒を原因食 とする食中毒が目立つて多くなつてきた。その際の原因 の多くはブドウ球菌による場合が主であるようである。 かかる特有の食物, とくに糖分の含有量が多い加工食品 がいかなる機序によつて中毒原因食品となるかといらこ とはきわ的て食中毒学上重要な問題である。甘酒を原因 食とする食中毒が近年注目されてきたに拘らず，これら に関連する諸問題は, まつたく解決されていないので, 食 中毒の発生機序を解明するとこにより, その予防対策京 成立せんこして, 甘酒に関する食中毒学的研究ならでに 成因の機序に関する実験字実施した。まず，甘酒学原因 食とする食中毒の発生状況につき疫学の面よりみた基䂰 的な分析が終了したので, まず第I報として, その成績 の概要をここに報告する。

\section{II. 資料ならびにその整理法}

甘酒食中毒事例况厚生省公衆衞生局環境衞生部食品衞 生課編の全国食中毒事件録 ${ }^{11}$ ならでに厚生省に各都道府 県より報告された食中毒報告書類字基礎資料こて調查し した。な拝正確定期与るために発生地の都道府県の食中 毒担当課に間い合わ立て，資料につき吟味字重放た：。亦 扮疫学的分析の調查期間注昭和 $30,31,32$ 年の 3 年間在 中心として，一部队昭和 25 年の事例学取り扱心，その分 析法は石川3゙ が検討したタコ食中毒の場合に準じて実沲 した。

\section{III. 疫学的調查研究成績}

\section{1. 甘酒食中毒発生状況の実態}

厚生省食品衛生課編の全国食中毒事件録によればH们 30 年以降昭和 32 年までに甘酒省原因食として発生した食 中毒第1表のどとくであつた。すなうち 3 年間で 20

第 1 表 昭和 30 年 32 年甘酒食中毒発生状況 (厚生省)

\begin{tabular}{|c|c|c|c|}
\hline 発生年度 & 件 & 患 者 数 & 死亡 数 \\
\hline 昭和 30 年 & 8 & 219 & 0 \\
\hline 昭和 31 年 & 9 & 307 & 1 \\
\hline 昭和 32 年 & 3 & 61 & 0 \\
\hline 計 & 20 & 587 & 1 \\
\hline
\end{tabular}

件，587名の甘酒食中毒患者が発生している。発生件数 に比して発生患者数が多いのが特徴で，1件当たり平均 29.3名となつている。とれは前述のどとくなんらかの機 会に多数人員が甘酒学摂食した事例があるためと少数発。 
生の届出が少ないことによるためと考元られる。また甘 酒食中毒発生件数々全食中毒発生件数を比較すると全食 中毒発生件数任昭和 30 年 3,277 件, 昭和 31 年 1,665 件, 昭 和 32 年 1,716 件であるから甘酒食中毒発生の千分比㥙炤 和 30 年 $2.44 \%$ ，昭和 31 年 $5.46 \%$, 昭和 32 年 $1.75 \%$ 上なり， 他方甘酒食中毒発生患者数々全食中毒発生患者数を比較 すると，乙の千分比注昭和 30 年 $3.4 \%$ ，昭和 31 年 10.9 $\%$ ，昭和 32 年 $2.5 \%$ に相当した。な予過去 3 年間で甘酒 食中毒による死亡患者数は 1 名のみである。これは岡山 県下で昭和 31 年 12 月 25 日に 1 名が掑食して発病した事例 であるが, 症状乞の他の詳細が不明でするため, 死因と 食中毒との関連を明らかにするここができない。第1表 に示された数字性甘酒が食中毒原因食已確認された事例 の及で，その他未報告の事例在も含奻之上実際の甘酒 食中毒の発生はさらに本資料ょり上回るもの上考元られ る。また甘酒食中毒の原因を確認した 報告は昭和 30 年 1 件, 昭和 31 年 0 件, 昭和 32 年 0 件で漂之えど不明とい 了結果が得られている。な招その病因物質が 報告され た1件はブドウ球菌であるとされ，食中毒検体よりエ ンテロトキシン産生ブドウ球菌を検出している。発生 時期より分析してみると, 昭和 30 年, 昭和 31 年の 2 年間 の 14 件では 3 月 1 件, 4 月 1 件, 5 月 3 件, 9 月 3 件, 10

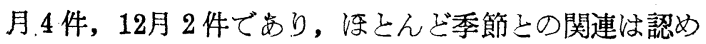
られない。秋季に比較的多い傾向に農産物の収穫期に あたり，村祭などの祝日があり，したがつて甘酒の提 食機会が多いためと考えられる。10例の資料では材料の

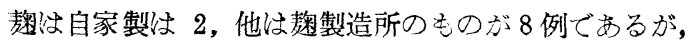
甘酒自体はいずれも自家製であつた(第 2 表)。なお甘酒

\section{第 2 表 甘酒食中発生件数と} 使用邀との関係

\begin{tabular}{c|c|c}
\hline & 䴴 & 甘 \\
\cline { 1 - 2 } 自 家 製 & 2 & 10 \\
製造所製 & 8 & 0 \\
\hline
\end{tabular}

食中毒発生を地域別に考察したととろ例数が少ないため 比らかな特殊性は認められなかつたが，農村地帯に多 く発生している傾向は認められた。

\section{2. 甘酒会中㱟事例の解析}

甘酒食中毒は前述のごとき発生状況であるが，事例の 詳細なる報告が少ないので, 全例について発病状況を解 析することはできなかつた。このために昭和25年以降厚 生省食品衙生課に詳報された甘酒中毒事例つ10件 384 名 在選びそれ认ついてその発病率, 潜伏時間, 発症患者年
柃，性別特色，発症症状，罯患時間などについて検討を おこなつた。な打10件中病因物質の確認されたものは昭 和 25 年 10 月の徳島県, 昭和 30 年 9 月の岡山県で発生した 2 件で，いずれもブドウ球菌毒素であるとされている汪 かは不明であつた。

\section{a. 甘酒食中毒詳報事例执よび発病率}

基礎資料とした10件の本中毒事例の発生年月日，発生 県, 摄食者, 発病率は第 3 表のと招りである。10件の合 部では摄食者数 734 名, 発症患者数 384 名であり平均発

第 3 表 甘酒全中烈 10 件の発病率, 病因物所

\begin{tabular}{|c|c|c|c|c|c|c|}
\hline 記号 & 発生年月日 & 発生県 & 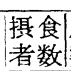 & 患者 & 発病率 & 病因物質 \\
\hline 1 & $\mid \begin{array}{lll}25 . & 10 . & 12\end{array}$ & 德 島 & 60 & 45 & $75.0 \%$ & ブドウ球菌 \\
\hline 2 & 25. 12.10 & 群 馬 & 7 & 7 & $100.0 \%$ & 不 \\
\hline 3 & 25. 12.19 & 群 馬 & 4 & 4 & $100.0 \%$ & 不 \\
\hline 4 & 26. 10.13 & 徳 島 & 49 & 43 & $87.7 \%$ & 明 \\
\hline 5 & $28 . \quad 8.26$ & 広 島 & 18 & 18 & $100.0 \%$ & 不 \\
\hline 6 & 29. $12 . \quad 8$ & 三 重 & 5 & 5 & $100.0 \%$ & 明 \\
\hline 7 & $\begin{array}{lll}30 . & 5 . & 3\end{array}$ & 岡 山 & 225 & 54 & $\%$ & $\begin{array}{l}\text { ブドウ球菌 } \\
\text { (推定) }\end{array}$ \\
\hline 8 & $\begin{array}{lll}30 . & 9 . & 6\end{array}$ & 岡 山 & 171 & 137 & $80.1 \%$ & ブドウ球菌 \\
\hline 9 & $\begin{array}{lll}30 . & 9 . & 30\end{array}$ & 和歌山 & 63 & 22 & $34.9 \%$ & 不 \\
\hline 10 & 32. 10.4 & 福 岡 & 132 & 49 & $37.1 \%$ & 明 \\
\hline & मा & & 734 & 384 & $52.3 \%$ & \\
\hline
\end{tabular}

病率 $52.3 \%$ となつているが，事例 7 の岡山県の事例孝除 外すれば発病率は $64.8 \%$ となりらに高率の発症という ことになる。打本資料の範囲で收死亡例は認められて いない。

b. 甘酒食中毒発症患者年龄別，性別分布

前記 384名の年龄区分を集計したものが第 4 表であ

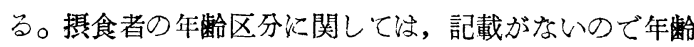
別発症率を検討するととはできなかつたが，患者の年龄 分布よりみると，10歳以下で $25.8 \% ， 20$ 墄以下で $38.5 \%$ を占めているの㖺好上若年者仁甘酒が多く摄食される

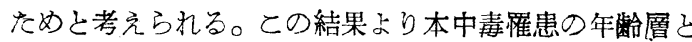
してはかなり広い範囲にわたつているという特性を見出 した。また発生患者 384 名の性別区分でば男子 172 名 (44.8\%),女子 212 名 (55.2\%) となり，女子にわずか 多発の傾向が認められているが，これも女子に扔ける撮 食者が多い結果已推定される。

c. 潜伏時間

調査対象の食中毒事例 384名について甘酒摄食時より 発症までの時間を分析したのが第 5 表である。摂食後よ 
第 4 表 甘酒余中串者 384 名の年龄分布

\begin{tabular}{c|c|c|c|c|c|c|c|c|c}
\hline 年柃区分 & $1 \sim 10$ & $11 \sim 20$ & $21 \sim 30$ & $31 \sim 40$ & $41 \sim 50$ & $51 \sim 60$ & $61 \sim 70$ & 71 以上 & 計 \\
\hline 患者 数 & 99 & 49 & 32 & 51 & 40 & 46 & 37 & 30 & 384 \\
\hline$\%$ & 25.8 & 12.8 & 8.3 & 13.3 & 10.4 & 12.0 & 9.6 & 7.8 & $100.0 \%$ \\
\hline
\end{tabular}

第 5 表 甘酒食中智伏時間（\%)

\begin{tabular}{|c|c|c|c|c|c|c|c|c|c|c|c|c|c|}
\hline 時間 & $\begin{array}{l}0 \\
l \\
2\end{array}$ & $\begin{array}{l}2 \\
1 \\
4\end{array}$ & $\begin{array}{l}4 \\
\imath \\
6\end{array}$ & $\begin{array}{l}6 \\
? \\
8\end{array}$ & $\begin{array}{c}8 \\
2 \\
10\end{array}$ & $\begin{array}{c}10 \\
1 \\
12\end{array}$ & $\begin{array}{c}12 \\
2 \\
14\end{array}$ & $\begin{array}{c}14 \\
2 \\
16\end{array}$ & $\begin{array}{c}16 \\
\text { ? } \\
18\end{array}$ & $\begin{array}{c}18 \\
2 \\
20\end{array}$ & $\begin{array}{c}20 \\
1 \\
22\end{array}$ & $\begin{array}{c}22 \\
\text { l } \\
24\end{array}$ & 計 \\
\hline 1 & $\begin{array}{c}8 \\
(17.7)\end{array}$ & $\begin{array}{c}22 \\
(46.6)\end{array}$ & $\begin{array}{c}5 \\
(11.1)\end{array}$ & $\begin{array}{c}6 \\
(13.3)\end{array}$ & $\begin{array}{c}3 \\
(6.6)\end{array}$ & $\begin{array}{c}1 \\
(2.2)\end{array}$ & 0 & 0 & 0 & 0 & 0 & 0 & 45 \\
\hline 2 & 0 & 7 & 0 & 0 & 0 & 0 & 0 & 0 & 0 & 0 & 0 & 0 & 7 \\
\hline 3 & 0 & 4 & 0 & 0 & 0 & 0 & 0 & 0 & 0 & 0 & 0 & 0 & 4 \\
\hline 4 & $\begin{array}{c}2 \\
(4.7)\end{array}$ & $\begin{array}{c}18 \\
(41.9)\end{array}$ & $\begin{array}{c}16 \\
(37.2)\end{array}$ & $\begin{array}{c}3 \\
(7.0)\end{array}$ & $\begin{array}{c}2 \\
(4.7)\end{array}$ & $\begin{array}{c}2 \\
(4.7)\end{array}$ & 0 & 0 & 0 & 0 & 0 & 0 & 43 \\
\hline 5 & 0 & 0 & 0 & 0 & $\begin{array}{c}3 \\
(16.7)\end{array}$ & $\begin{array}{c}4 \\
(22.2)\end{array}$ & $\begin{array}{c}6 \\
(33.3)\end{array}$ & $\begin{array}{c}1 \\
(5.6)\end{array}$ & 0 & $\begin{array}{c}3 \\
(16.7)\end{array}$ & $\frac{1}{5.6)}$ & 0 & 18 \\
\hline 6 & 0 & $\begin{array}{c}3 \\
(60)\end{array}$ & $\begin{array}{c}1 \\
(20)\end{array}$ & $\begin{array}{c}1 \\
(20)\end{array}$ & 0 & 0 & 0 & 0 & 0 & 0 & 0 & 0 & 5 \\
\hline 7 & $\begin{array}{c}18 \\
(33.3)\end{array}$ & $\begin{array}{c}21 \\
(38.8)\end{array}$ & ) $\begin{array}{c}12 \\
(22.2)\end{array}$ & $\begin{array}{c}2 \\
(3.5)\end{array}$ & $\begin{array}{c}1 \\
(1.8)\end{array}$ & 0 & 0 & 0 & 0 & 0 & 0 & 0 & 54 \\
\hline 8 & $\begin{array}{c}36 \\
(26.3)\end{array}$ & $\begin{array}{c}82 \\
(59.9)\end{array}$ & $\begin{array}{c}17 \\
(12.4)\end{array}$ & $\begin{array}{c}1 \\
(0.7)\end{array}$ & $\begin{array}{c}1 \\
(0.7)\end{array}$ & 0 & 0 & 0 & 0 & 0 & 0 & 0 & 137 \\
\hline 9 & $\begin{array}{c}13 \\
(54.5)\end{array}$ & $\left(31^{7} .8\right)$ & $\begin{array}{c}1 \\
(4.5)\end{array}$ & 0 & 0 & 0 & 0 & $\begin{array}{c}1 \\
(4.5)\end{array}$ & 0 & 0 & 0 & 0 & 22 \\
\hline 10 & $\begin{array}{c}21 \\
(48.1)\end{array}$ & $\begin{array}{c}17 \\
(34.6)\end{array}$ & $\begin{array}{c}11 \\
(22.4)\end{array}$ & 0 & 0 & 0 & 0 & 0 & 0 & 0 & 0 & 0 & 49 \\
\hline 計 & 98 & 181 & 63 & 13 & 10 & 7 & 6 & 2 & 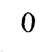 & 3 & 1 & 0 & 384 \\
\hline$\%$ & 25.5 & 49.1 & 16.4 & 3.4 & 2.6 & 1.9 & 1.6 & 0.5 & 0 & 0.8 & 0.3 & 0 & 100.0 \\
\hline
\end{tabular}

第 1 図 潜伏時間の分布 $(\%)$

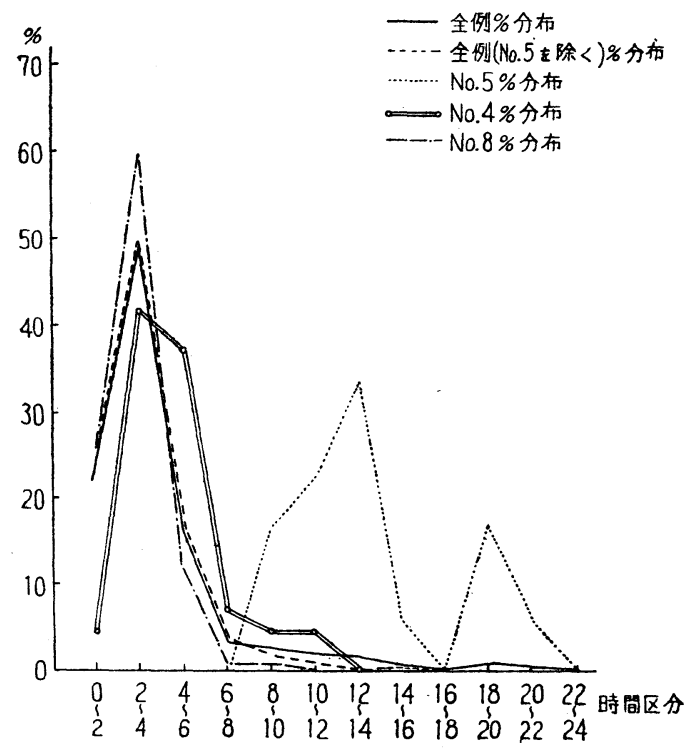

り 2 時間ごとの時間区分で集計した場合, 中毒事例より 考察すると摂食後 2 時間以内に発症した事例は10例中 6 例， 4 時間以内では 事例 5 除いた 9 例が 初発患者の 発症をみている。すなわち 10 例中 1 例在除きすべて 4 時 間以内の発症事例であつた。全患者数から発症時間をみ る己 4 時間以内に 279 名 (74.6\%) が発症しているとい 了結果得た。事例 5 驻昭和28年 8 月に広島県で発生 した甘酒食中毒であるが第 5 表に示すごとく他の症例と は異なり患者18名の初発患者は摂食後よりかなり遅く, 提食後 8 時間以降に発症し，他の例にまつたく異なる型 であつた。発症時間があつとも遅い事例治や络り事例 5 で，20２2時間であつた。な招その全例㧍よび発症例の 多い事例の潜伏時間を第 1 図として参考のために示して 打く。調査対象上なつた 10 例の甘酒食中毒では本事例学 除いては全般的にみて潜伏時間がきわめて短いという結 果老得た。

d. 主要症状 
第 6 表 甘酒军中垡要症状

\begin{tabular}{c|r|r|r|r|r|r|r|r}
\hline 記号 & 患者数 & 嘔 吐 & \multicolumn{1}{|c|}{ 下 痢 } & 腹 痛 & 頭 痛 & 悪感 & 発 熱 & 心臟衰弱 \\
\hline 1 & 45 & $45(100.0)$ & $11(24.2)$ & $16(35.2)$ & $45(100.0)$ & $28(61.6)$ & $6(13.2)$ & $0(0)$ \\
2 & 7 & $7(100.0)$ & $7(100.0)$ & $7(100.0)$ & $3(42.9)$ & $7(100.0)$ & $0(0)$ & $2(28.6)$ \\
3 & 4 & $4(100.0)$ & $4(100.0)$ & $4(100.0)$ & $4(100.0)$ & $4(100.0)$ & $1(25.0)$ & $1(25.0)$ \\
4 & 43 & $40(92.0)$ & $29(66.7)$ & $21(48.3)$ & $28(64.6)$ & $34(78.2)$ & $4(10.2)$ & $0(0)$ \\
5 & 18 & $16(89.6)$ & $17(95.2)$ & $18(100.0)$ & $18(100.0)$ & $18(100.0)$ & $18(100.0)$ & $0(0)$ \\
6 & 5 & $5(100.0)$ & $5(100.0)$ & $5(100.0)$ & $5(100.0)$ & $5(100.0)$ & $5(100.0)$ & $0(0)$ \\
7 & 54 & $54(100.0)$ & $22(41.8)$ & $27(51.3)$ & $0(0)$ & $54(100.0)$ & $0(0)$ & $0(0)$ \\
8 & 137 & $122(89.1)$ & $39(28.5)$ & $58(42.3)$ & $46(26.6)$ & $68(49.6)$ & $37(27.0)$ & $0(0)$ \\
9 & 22 & $22(100.0)$ & $10(45.0)$ & $7(31.5)$ & $6(27.0)$ & $18(81.0)$ & $0(0)$ & $0(0)$ \\
10 & 49 & $49(100.0)$ & $0(0)$ & $49(100.0)$ & $49(100.0)$ & $47(98.7)$ & $0(0)$ & $6(12.6)$ \\
\hline 計 & 384 & 364 & 199 & 212 & 204 & 283 & 71 & 9 \\
\hline$\%$ & 100.0 & 94.6 & 51.7 & 65.1 & 53.0 & 73.6 & 18.5 & 2.3 \\
\hline
\end{tabular}

前記甘酒食中毒事例10例 384名の主要症状は第 6 表の ごとくであつた。本資料は食中毒発生地の所管保健所扮 よび衛生研究所によつて調查されたものである関係上, 調査項目が統一されていないため頭痛，心臓衰弱に関し ては報告されていない事例もあるが，关の他の項目牥ず べて共通項目であつた。もつとも発症頻度の高いもの绾 呕吐 $(94.6 \%)$, 悪感 $(73.6 \%)$, 腹痛 $(65.1 \%)$ であり， そのほか下痢, 頭痛などが約半数の患者に認められた。 潜伏時間より 久て特殊な発症形態を示したこ考えられる 事例 5 は 発症症状においても他の 中毒事例之 異なり熱 発, 腹痛, 頭痛, 悪感が $100 \%$ k認められた。熱発牥 $37^{\circ} \mathrm{C} \sim 38^{\circ} \mathrm{C} 3$ 名, $38^{\circ} \mathrm{C} \sim 39^{\circ} \mathrm{C} 14$ 名, $39^{\circ} \mathrm{C} \sim 40^{\circ} \mathrm{C} 1$ 名之心 了状況て他の事例と異なりかなりの高熱であり，他症例 発熱者 53 名注 $37^{\circ} \mathrm{C} \sim 38^{\circ} \mathrm{C} 39$ 名 $(73.6 \%), 38^{\circ} \mathrm{C} \sim 39^{\circ} \mathrm{C} 10$ 名 $(18.8 \%), 39^{\circ} \mathrm{C} \sim 40^{\circ} \mathrm{C} 4$ 名 $(7.6 \%)$ で比較的軽度で品 つた。呕吐峙発症症状のうちその率が最高であり，他症 状に先だつて発現する。呕吐回数注最少 2 回, 最多 25 回 已報告されて怙り詳細结不明であるが $5 〜 10$ 回前後がす つとも多い。激烈なものは 4 時閒連続して呕吐せる症例 をあり，胆汁样物質を吐いたと記載されている。太た呕 吐飞伴つて呕気, 胃部不快感を訴えている場合が多い。 下痢を訴元た患者 199 名仙ついてその回数別分布状態を 検討すると，最少 1 回，最多 20 回であり，下㢉 $1 \sim 5$ 回 102名 (51.3\%), 6 10回67名 (33.7\%), 11 15回27名

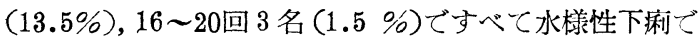
あつた。な抢水様便中に粘液様物質，血液を混えたと報 告したものが 4 例存在したが，乙れらは下痢回数11回以 上の事例であつた。後述のごとく各検查機関によつて検 討されたが血便の原因とみなされる既知病原細菌の検出
されたものはなかつた。腹痛は 212 名(65.1\%)が報告さ れているが, 腹痛部位としては臍部、下腹部が大部分で， 膨満感を併発しているものが多かつた。詳細の報告は不 明であるが，相当激烈な疼痛索訴えている症例が28名存 在した。心臟衰弱は自覚症状として9名 ( $2.3 \%)$ k認 められているが，いずれも照合の結果他覚的に心臓所見 掠よび脈搏に変化が認められない。故に心臟衰弱感上呼 ぶべきもので，乙れらは呕吐, 腹痛の激しいものにみら れ，随伴的症状とも考元られる。

\section{e. 治癒時間}

発症より治瘉したと認められるまでの時間を罹病時間 とすると，全患者数 384 名中 221 名 (57.7\%) が12時間 以内に，98名 (25.5\%) が24㭙間以内に，54名 (14.1\%) が36時間以内に治癒していると報告している。残り11名 （2.8\%）も48時間以内に流々九ご症状が軽快してい る。事例 5 の患者の多くは48時間であつた。すなわち大 部分の食中毒患者 319 名 (83.2\%) が24時間以内に恢復 し，予後は心つたく良好であり，経過恃速やかであつた といえる。しかし事例 5 は治癒時間が長いことから考充 て，必ずしも食中毒として軽いとはいえない。

\section{3. 真中憲患者検查諸成絃}

前述の甘酒学原因食として発生した食中毒事例10件に ついて, 著者らはその食中毒発生の規模, 発症症状なぞ を疫学的に考察した。乙れらの食中毒に対しては, 検査 機関すなわち各保健所抢よび衛生研究所によつて綿密な 諸検査が実施されて，その一部は厚生省に報告されてい る。著者らは, この報告を基礎にして, 一部は各食中毒 発生地に照合を执こなつて, その成績に分析を加えてみ た。 


\section{a. 垐便検查成績}

前記10件の甘酒食中毒事例中 6 件 134名の粪便検査成 績の結果が判明している。糞便検体については各研究機 関とも普通寒天培地， S S 寒天培地による細菌分離を実 湤し， 2 件 92 検体に揖いてさらに遠藤寒天培地在使用し ている。また増菌培地として胆汁ブイヨンおよびブドウ 糖加ペプトン水を使用している事例もあるが結果は同様 であつた。さらに分離菌の糖分解能抢よび血清学的検査 などにより既知腸管系病原菌の検出安実施しているが 1 例も見出されていない。ただし各例とも検查対照を赤梸 菌, チフス菌, その他のサルモネラ菌に限定している傾 向があり, 䀺便よりの病原性大腸菌, プロテウス菌など に関しての箃密な検査はないようであり, また嫌気性菌 についての検索も実施されていなかつた。

\section{b. 吐物検查}

吐物に関して検查を実施した事例はわずかで，3件 7 検体の及が $\mathrm{S} \mathrm{S}$ 寒天, 血液寒天, 普通寒天などを使用し て同椂に病原菌の検出䒠施しているが，究明しえた報 告はない。こくに吐物については，黄色ブドウ球菌の検 出のみに重点を抢いて検索された結果でも，それらは検 出されていない。

\section{c. 患者血液}

著者らが調査した範囲では，2 事例， 4 検体の患者血 液について糞便に関する細菌学的検索と同様に増菌およ び菌分離が実施されている。群馬県における事例 2 では 分離菌 $\mathrm{Bu}$ 株が生物学的性状に扮いては Salmonella 菌 属に一致するが血清学的性状に捛いては Salmonella に 一致するものがなく，患者血清との間にも抗原，抗体反 応が認められていない。

\section{考按}

本邦の食中毒の発生状況に関する疫学的考察の総括以 机沢の「食品衞生学」2) に詳述されているので省略する が，その原因食品の多くは動物性食品であつて，とのう ちでむこくに多いのはイカ，タコなどを原因食とする食 中毒であり，乙れらに関しては竹内，石川3゙らよつ て, 詳細なる研究が当研究室で実施された。炭水化物を 主成分とした植物性食品による場合は有毒植物による中 毒以外は比較的少ない。近年これらの植物性加工食品 中，化学性食中毒こみなされ好もので注目されたのが， まず約納豆であつて，これはすでに松本"によよつて詳 細に検討され，その成因について多くの知見が 提供さ れている。現在問題になつているのは，ろぐいす豆 ${ }^{5)}$
本研究の対象食品である甘酒原因食とする食中毒であ ろら。著者は, 食中毒の原因抬よびその発生防止に関す る基礎的な概念を研究するに際しては，その発生した甘 酒食中毒に関する疫学的研究老実施するのがまず第一の 条件と考え，厚生省食品衞生課の配慮に占り，得られた 資料について分析を実施した。この疫学的研究成績によ ると，甘酒が家庭的な食物と考えられるにも拘らず，意 外に集団的発生が認められている。との問題は原料と なる出靝での一次的污染专るいは甘酒の製造工程中で の食中毒菌の混入増殖があつたものとも考えられるし， なた集団的な会合に際して提供されやすい食品である ためともいえる。患者の発病率, 発症症状などより考 えると, その病因注化学性食中毒のうちの化学物質に よる食中毒というょりも, 細菌性食中毒と考察する方 が妥当という結果が得られた。またさらに細菌性食中 毒のうらで, ブドウ球菌のエンテロトキシンによると考 えられる中毒発症状況であつたといえる。なおブドウ球 菌食中毒こして判明した中毒事例もわずかながらある。 甘酒の製造工程は次回に報告するが，飲用に際して， 加熱して温いものとして摂食されるのが普通であること を考えると，感染型食中毒原因細菌であるサルモネラそ の他の食中毒原因細菌では，それらの菌が存在していて も死隇するか，あるいは菌量が減少するので，中毒発生 の可能性が少なくなり，そのために感染型食中毒の発生 が毒素型より少ないとも考察される。しかし 分析を招 こなつた事例のうち感染型と推定されるものもあり, 昭和 32 年 5 月 15 日愛知県渥美郡田原町に発生した自家製 の甘酒食中毒（患者数 7 名，死亡0 名）の例の原因は Sal. posdam であるということも判明していることより 考察すると, 甘酒の食中毒では感染型食中毒も発生例が 少ないが考慮しなければならない。細菌性食中毒であれ 㳊，当然発生月別推移について 5〜9月に多発をみるの が動物性食品の場合は原則であるが，本中毒では必ずし もこの傾向が強く現われてこないことより考察すると， その製造工程との関連が介在するということ省考えなけ れ汸ならない。甘酒存因食とする食中毒の発生状況䘮 疫学的に分析し結果, その成因に関する二,三の要点を 把握しえたが，現在化学性食中毒と考えられる食中毒事 例の発生はないようである。しかし当然合成甘味料偟よ る場合上か，あるいは自家製の場合が多い関係上，乙と に環境衛生上やや不良といえる場合の多い農家でつくら れるだけに有害物質の誤用に基づく化学物質による食中 毒も考えなければならないのは当然であうう。 


\section{結論}

近年とくに植物性食品の食中毒として注目されてきた 甘酒を原因食とする食中毒事例に関して，厚生省に報告 された資料に基づき疫学的な解析を試みた。甘酒は植物

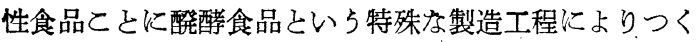
られる食品であるが，乙れによる食中毒の発生状況を解 析した結果，必ずしも発生頻度が少ないということはな く，ととに患者数が多く，弱年者も発症する機会がある ので食中毒学上問題としなければならぬ中毒であるとい ろことが判明した。本中毒の原因は, 発症時間, 症状, 予後などを検討した結果より, 細菌性食中毒のうちの毒 素型が多いと考えられるが，しかし感染型と考えられる 事例すわずかであるが存在することも明らかにされた。 甘酒が多く農村で製造, 飲用されることは, 農家の環境 衙生条件と相まつて, 甘酒食中毒が今後も農村仙頻発す るととを推測させる。
本論交要旨の一部は昭和 33 年第 13 回日本公衆衙生学 会に扣いて発表した。

本稿を終るに臨み御指導, 御校閲を賜わつた恩師柳沢 交德教授ならびに実験指道に当たられた竹内端彌助教授 に深く感謝の意を表する次第であります。まえ実験に際 し種々御便宜を賜わつた日本種槒協会の御厚意飞深く感 謝いたします。

\section{文献}

1）厚生省公衆衛生局環境衛生部食品衛生課編：全 国食中毒事件録，昭和 30 年，昭和 31 年，昭和 32 年.

2）柳沢交徳：食品衛生学, 樍交堂, 1958.

3）石川一：扣茶の水医学雑誌， $6,8,1958$.

4）松本埪：日本衛生学雑誌，9，244，1955.

5）田中博：日本公采衛生雑誌, 5 (増刊号), 89, 1958.

（受付：1959 年 7 月 1 日，特別掲載） 